\title{
Clinical Characteristics of Patients Hospitalized with Coronavirus Disease, Thailand
}

Wannarat A. Pongpirul, Joshua A. Mott, Joseph V. Woodring, Timothy M. Uyeki, John R. MacArthur, Apichart Vachiraphan, Pawita Suwanvattana, Sumonmal Uttayamakul, Supamit Chunsuttiwat, Tawee Chotpitayasunondh, Krit Pongpirul, Wisit Prasithsirikul

Among 11 patients in Thailand infected with severe acute respiratory syndrome coronavirus 2 , we detected viral RNA in upper respiratory specimens a median of 14 days after illness onset and 9 days after fever resolution. We identified viral co-infections and an asymptomatic person with detectable virus RNA in serial tests. We describe implications for surveillance.

D uring January 2020, persons in Thailand were tested for the presence of severe acute respiratory syndrome coronavirus 2 (SARS-CoV-2) infection if they had a combination of fever or respiratory illness and a history of travel to Wuhan, China. Persons determined to be close contacts of a laboratory-confirmed coronavirus disease (COVID-19) case-patient also were tested during enrollment into contact tracing. Clinicians were able to request testing if they had a concern regarding persons who were exposed to travelers. During January 8-31, 2020, Bamrasnaradura Infectious Diseases Institute, the national infectious disease referral hospital in Bangkok, admitted 11 patients with laboratoryconfirmed COVID-19. We describe clinical features, clinical management, and results of serial reverse transcription PCR (RT-PCR) testing for SARS-CoV-2 RNA for these patients.

Author affiliations: Bamrasnaradura Infectious Diseases Institute, Bangkok, Thailand (W.A. Pongpirul, A. Vachiraphan,

P. Suwanvattana, S. Uttayamakul, W. Prasithsirikul); US Centers for Disease Control and Prevention-Thailand Ministry of Public Health Collaboration, Bangkok (J.A. Mott, J.V. Woodring, J.R. MacArthur); US Centers for Disease Control and Prevention, Atlanta, Georgia, USA (T.M. Uyeki); Thailand Ministry of Public Health, Bangkok (S. Chunsuttiwat); Queen Sirikit National Institute for Child Health, Bangkok (T. Chotpitayasunondh); Chulalongkorn University, Bangkok (K. Pongpirul)

DOI: https://doi.org/10.3201/eid2607.200598

\section{The Study}

The 11 hospitalized patients had daily nasopharyngeal and oropharyngeal sampling for SARS-CoV-2 RNA testing. Specimens were collected by using synthetic fiber swabs, which were combined and placed into a single sterile tube containing $» 3 \mathrm{~mL}$ of viral transport medium. RNA was extracted and tested with conventional RT-PCR and real-time RT-PCR (rRT-PCR). We developed SARS-CoV-2-specific primers and probes by using a protocol from the World Health Organization (1) and validated results by using clinical specimens. Nasopharyngeal and oropharyngeal swabs and sputum specimens also were tested for 33 respiratory pathogens by using the Fast-Track Diagnostic rRT-PCR Respiratory Panel (Fast Track Diagnostics, http:/ /www.fast-trackdiagnostics.com), according to the manufacturer's instructions. During the study period, Thailand's discharge criteria for hospitalized COVID-19 patients required resolution of clinical signs and symptoms and 2 respiratory specimens without detectable SARS-CoV-2 RNA collected $\geq 24$ hours apart.

The median age of the patients was 61 years (range 28-74 years; Table 1). Cough, malaise, and sore throat were the most common signs and symptoms among the 11 patients (Figure 1). In patients with fever (temperature $>38^{\circ} \mathrm{C} ; 10 / 11$ ), defervescence took a median of 6 days (4-11.5 days). Some patients had signs and symptoms that lasted $\geq 10$ days (Figure 1; Table 2). Most patients received supportive care; none required mechanical or noninvasive ventilation during their hospitalization.

Patient 4 remained asymptomatic throughout hospitalization despite daily monitoring. However, her chest radiograph at admission revealed unilateral pneumonia (Appendix Figure, http://wwwnc.cdc. gov/EID/article/26/7/20-0598-App1.pdf). Patient 4 's nasopharyngeal and oropharyngeal specimens had detectable SARS-CoV-2 RNA on 4 consecutive 
days. She finally had 2 negative specimens separated by $\geq 24$ hours and was discharged on day 7 after symptom onset (Figure 2).
Patient 10, a taxi driver with no history of air travel, had the most severe clinical presentation among these cases (2). He reported close contact

Table 1. Demographics, baseline characteristics, illness histories, laboratory values and treatment therapies of confirmed COVID-19 patients in Bamrasnaradura Infectious Diseases Institute, Bangkok, Thailand, 2020*

\begin{tabular}{|c|c|c|c|c|c|c|c|c|c|c|c|c|}
\hline \multirow[b]{2}{*}{ Demographics } & \multicolumn{11}{|c|}{ Patient no. } & \multirow[b]{2}{*}{ Total, \% } \\
\hline & 1 & 2 & 3 & 4 & 5 & 6 & 7 & 8 & 9 & 10† & 11 & \\
\hline Age, y/sex & $61 / F$ & $74 / F$ & $68 / \mathrm{M}$ & $66 / F$ & $57 / F$ & $34 / \mathrm{M}$ & $61 / \mathrm{M}$ & 63/M & $28 / F$ & $51 / \mathrm{M}$ & $49 / \mathrm{M}$ & $55 \mathrm{M} / 45 \mathrm{~F}$ \\
\hline Ethnicity & $\mathrm{CH}$ & $\mathrm{CH}$ & $\mathrm{CH}$ & $\mathrm{CH}$ & $\mathrm{CH}$ & $\mathrm{CH}$ & $\mathrm{CH}$ & $\mathrm{CH}$ & $\mathrm{CH}$ & $\mathrm{TH}$ & $\mathrm{TH}$ & $82 \mathrm{CH} / 18 \mathrm{TH}$ \\
\hline Occupation & Ret & Ret & Ret & Ret & Ret & EE & Ret & Ret & $\begin{array}{l}\text { Tour } \\
\text { guide }\end{array}$ & $\begin{array}{c}\text { Taxi } \\
\text { driver }\end{array}$ & Officer & 54 Ret/46 other \\
\hline Detected through airport screening & $\mathrm{Y}$ & $\mathrm{Y}$ & $\mathrm{Y}$ & $\mathrm{N}$ & $\mathrm{N}$ & $\mathrm{N}$ & $\mathrm{N}$ & $\mathrm{N}$ & $\mathrm{N}$ & $\mathrm{N}$ & $\mathrm{N}$ & $27 \mathrm{Y} / 73 \mathrm{~N}$ \\
\hline Detected through contact tracing & $\mathrm{N}$ & $\mathrm{N}$ & $\mathrm{N}$ & $\mathrm{Y}$ & $\mathrm{N}$ & $\mathrm{N}$ & $\mathrm{N}$ & $\mathrm{N}$ & $\mathrm{N}$ & $\mathrm{N}$ & $\mathrm{N}$ & $9 \mathrm{Y} / 91 \mathrm{~N}$ \\
\hline $\begin{array}{l}\text { Detected after patient voluntarily } \\
\text { sought medical care }\end{array}$ & $\mathrm{N}$ & $\mathrm{N}$ & $\mathrm{N}$ & $\mathrm{N}$ & $\mathrm{Y}$ & Y & Y & $\mathrm{Y}$ & Y & Y & Y & $64 \mathrm{Y} / 36 \mathrm{~N}$ \\
\hline Visited Hunan Seafood Market & $\mathrm{N}$ & $\mathrm{N}$ & $\mathrm{N}$ & $\mathrm{N}$ & $\mathrm{N}$ & $\mathrm{N}$ & $\mathrm{N}$ & $\mathrm{N}$ & $\mathrm{N}$ & $\mathrm{N}$ & $\mathrm{N}$ & 0 \\
\hline \multicolumn{13}{|l|}{ Underlying conditions } \\
\hline Diabetes & $\mathrm{N}$ & $\mathrm{N}$ & $\mathrm{N}$ & $\mathrm{N}$ & $\mathrm{N}$ & Y & $\mathrm{N}$ & $\mathrm{N}$ & $\mathrm{N}$ & Y & $\mathrm{N}$ & $18 \mathrm{Y} / 82 \mathrm{~N}$ \\
\hline Hypertension & Y & Y & $\mathrm{N}$ & Y & $\mathrm{N}$ & $\mathrm{N}$ & $\mathrm{N}$ & $\mathrm{N}$ & $\mathrm{N}$ & Y & $\mathrm{N}$ & $36 \mathrm{Y} / 64 \mathrm{~N}$ \\
\hline COPD & $\mathrm{N}$ & $\mathrm{N}$ & $\mathrm{N}$ & $\mathrm{N}$ & $\mathrm{N}$ & $\mathrm{N}$ & $\mathrm{N}$ & $\mathrm{N}$ & $\mathrm{N}$ & $\mathrm{N}$ & $\mathrm{N}$ & 0 \\
\hline Asthma & $\mathrm{N}$ & $\mathrm{N}$ & $\mathrm{N}$ & $\mathrm{N}$ & $\mathrm{N}$ & $\mathrm{N}$ & $\mathrm{N}$ & $\mathrm{N}$ & $\mathrm{N}$ & $\mathrm{N}$ & $\mathrm{N}$ & 0 \\
\hline Cancer & $\mathrm{N}$ & $\mathrm{N}$ & $\mathrm{N}$ & $\mathrm{N}$ & $\mathrm{N}$ & $\mathrm{N}$ & $\mathrm{N}$ & $\mathrm{N}$ & $\mathrm{N}$ & $\mathrm{N}$ & $\mathrm{N}$ & 0 \\
\hline Cardiovascular disease & $\mathrm{N}$ & Y & $\mathrm{N}$ & $\mathrm{Y}$ & $\mathrm{N}$ & $\mathrm{N}$ & $\mathrm{N}$ & $\mathrm{Y}$ & $\mathrm{N}$ & $\mathrm{N}$ & $\mathrm{N}$ & $27 \mathrm{Y} / 73 \mathrm{~N}$ \\
\hline Cerebrovascular disease & $\mathrm{N}$ & $\mathrm{N}$ & $\mathrm{N}$ & $\mathrm{N}$ & $\mathrm{N}$ & $\mathrm{N}$ & $\mathrm{N}$ & Y & $\mathrm{N}$ & $\mathrm{N}$ & $\mathrm{N}$ & $9 \mathrm{Y} / 91 \mathrm{~N}$ \\
\hline Chronic liver disease & $\mathrm{N}$ & $\mathrm{N}$ & $\mathrm{N}$ & $\mathrm{N}$ & $\mathrm{N}$ & $\mathrm{N}$ & $\mathrm{N}$ & $\mathrm{N}$ & $\mathrm{N}$ & $\mathrm{N}$ & $\mathrm{Y}$ & $9 \mathrm{Y} / 91 \mathrm{~N}$ \\
\hline Any chronic condition & Y & Y & $\mathrm{N}$ & Y & $\mathrm{N}$ & Y & $\mathrm{N}$ & Y & $\mathrm{N}$ & Y & Y & $64 \mathrm{Y} / 36 \mathrm{~N}$ \\
\hline Current smoker & $\mathrm{N}$ & $\mathrm{N}$ & $\mathrm{N}$ & $\mathrm{N}$ & $\mathrm{N}$ & $\mathrm{N}$ & $\mathrm{N}$ & $\mathrm{N}$ & $\mathrm{N}$ & $\mathrm{N}$ & $\mathrm{N}$ & 0 \\
\hline Pregnant & NA & NA & NA & NA & NA & NA & NA & NA & $\mathrm{N}$ & NA & NA & 0 \\
\hline \multicolumn{13}{|c|}{ Laboratory values at time of admission (reference range) } \\
\hline Leukocytes ×109/L (4.5-8) & $1.9 \downarrow$ & $3.3 \downarrow$ & 4 & 3.6 & 3.9 & $3.4 \downarrow$ & 5.8 & 4.1 & 4.9 & 5.8 & $2.5 \downarrow$ & \\
\hline Neutrophils, \% (36-70) & 48 & 64 & 66 & 63 & 56 & $80 \uparrow$ & 63 & 83 & $73 \uparrow$ & 58 & 54 & \\
\hline Lymphocytes, \% (23-57) & 40 & $19 \downarrow$ & 25 & 25 & 33 & $1 \downarrow$ & 30 & $16 \downarrow$ & 23 & 31 & 30 & \\
\hline Platelets $\times 10^{6} / \mu \mathrm{L}(140-400)$ & $127 \downarrow$ & $16.4 \downarrow$ & $12.6 \downarrow$ & 177 & 167 & 169 & 168 & $18.4 \downarrow$ & 153 & 368 & 167 & \\
\hline Hemoglobin, g/dL (11-14) & 13.3 & 12.8 & 11.5 & 13.1 & 13.2 & 13.3 & $15.3 \uparrow$ & 13.8 & 11.4 & 14 & $14.8 \uparrow$ & \\
\hline Hematocrit, \% (35-41) & 38 & 38 & $33 \downarrow$ & 37 & 37.9 & 38 & $45 \uparrow$ & 39 & 34 & 41 & $43 \uparrow$ & \\
\hline ALT, U/L (0-31) & 18 & 27 & 18 & $83 \uparrow$ & 23 & 16 & 22 & 22 & 24 & 24 & 26 & \\
\hline AST, U/L (0-31) & 14 & 12 & 15 & $47 \uparrow$ & 16 & 19 & 20 & 14 & 25 & 16 & 22 & \\
\hline \multicolumn{13}{|l|}{ Other diagnostics } \\
\hline $\begin{array}{l}\text { Oxygen saturation on room air at } \\
\text { admission }\end{array}$ & 98 & 97 & 95 & 98 & 99 & 99 & 98 & 99 & 96 & $91 \downarrow$ & 97 & \\
\hline \multicolumn{13}{|c|}{ Results from Biofire-33 multiplex PCR } \\
\hline Haemophilus influenzae & + & + & - & - & + & + & - & - & - & - & - & \\
\hline Adenovirus & - & + & - & - & - & - & - & - & - & - & - & \\
\hline Influenza A & - & - & - & - & - & - & + & - & - & - & - & \\
\hline Klebsiella pneumoniae & - & - & - & - & - & - & - & - & - & - & + & \\
\hline \multicolumn{13}{|l|}{ Treatments } \\
\hline \multicolumn{13}{|l|}{ Antimicrobial drugs, dose } \\
\hline Ceftriaxone, $2 \mathrm{~g} 4 \times / \mathrm{d}$ IV & 1 & 0 & 7 & 0 & 0 & 0 & 7 & 0 & 0 & 7 & 0 & \\
\hline Ceftriaxone, 2 g/d orally & 0 & 7 & 0 & 0 & 0 & 0 & 0 & 0 & 0 & 0 & 0 & \\
\hline AMOX/CLAV, 2 g 4×/d orally & 6 & 0 & 0 & 0 & 0 & 0 & 0 & 0 & 0 & 0 & 7 & \\
\hline Oseltamivir, $150 \mathrm{mg} \mathrm{4×/d} \mathrm{orally}$ & 5 & 0 & 0 & 0 & 0 & 0 & 5 & 0 & 0 & 0 & 5 & \\
\hline Nasal cannula, $5 \mathrm{~L}$, no. days & 0 & 0 & 0 & 0 & 0 & 0 & 0 & 0 & 0 & 3 & 0 & \\
\hline $\begin{array}{l}\text { Duration of signs and symptoms } \\
\text { reported at admission, d }\end{array}$ & & & & & & & & & & & & $\begin{array}{l}\text { Median (IQR)/ } \\
\text { mean (SD) }\end{array}$ \\
\hline Cough & 1 & 1 & 1 & 0 & 2 & 1 & 4 & 2 & 3 & 8 & 5 & $2(1-4) / 2.5(2.3)$ \\
\hline Malaise or fatigue & 4 & 2 & 4 & 0 & 2 & 4 & 13 & 2 & 3 & 5 & 5 & $4(2-5) / 4.0(3.3)$ \\
\hline Fever & 2 & 2 & 4 & 0 & 3 & 4 & 4 & 2 & 2 & 8 & 5 & $3(2-4) / 3.3(2.1)$ \\
\hline Sore throat & 4 & 0 & 3 & 0 & 3 & 2 & 4 & 2 & 3 & 7 & 5 & $3(2-4) / 3.0(2.0)$ \\
\hline Rhinorrhea & 2 & 2 & 4 & 0 & 2 & 1 & 3 & 2 & 2 & 2 & 4 & $2(2-3) / 2.2(1.2)$ \\
\hline Headache & 1 & 0 & 2 & 0 & 0 & 0 & 0 & 2 & 1 & 5 & 3 & $1(0-2) / 1.3(1.6)$ \\
\hline Vomiting & 0 & 1 & 1 & 0 & 0 & 0 & 0 & 1 & 0 & 0 & 0 & $0(0-1) / 0.3(0.5)$ \\
\hline Diarrhea & 0 & 0 & 1 & 0 & 0 & 0 & 0 & 1 & 0 & 0 & 0 & $0 / 0.2(0.4)$ \\
\hline
\end{tabular}

${ }^{*} \mathrm{ALT}$, alanine aminotransferase; AMOX/CLAV, amoxicillin/clavulanate; AST, aspartate aminotransferase; COVID-19, coronavirus disease; CH, Chinese; EE, electrical engineer; IV, intravenous; NA, not applicable; Ret, retired; TH, Thai; $\downarrow$, low; $\uparrow$, high; +, positive; -, negative. $\dagger(2)$

†BioFire Diagnostics (https://www.biofiredx.com) 


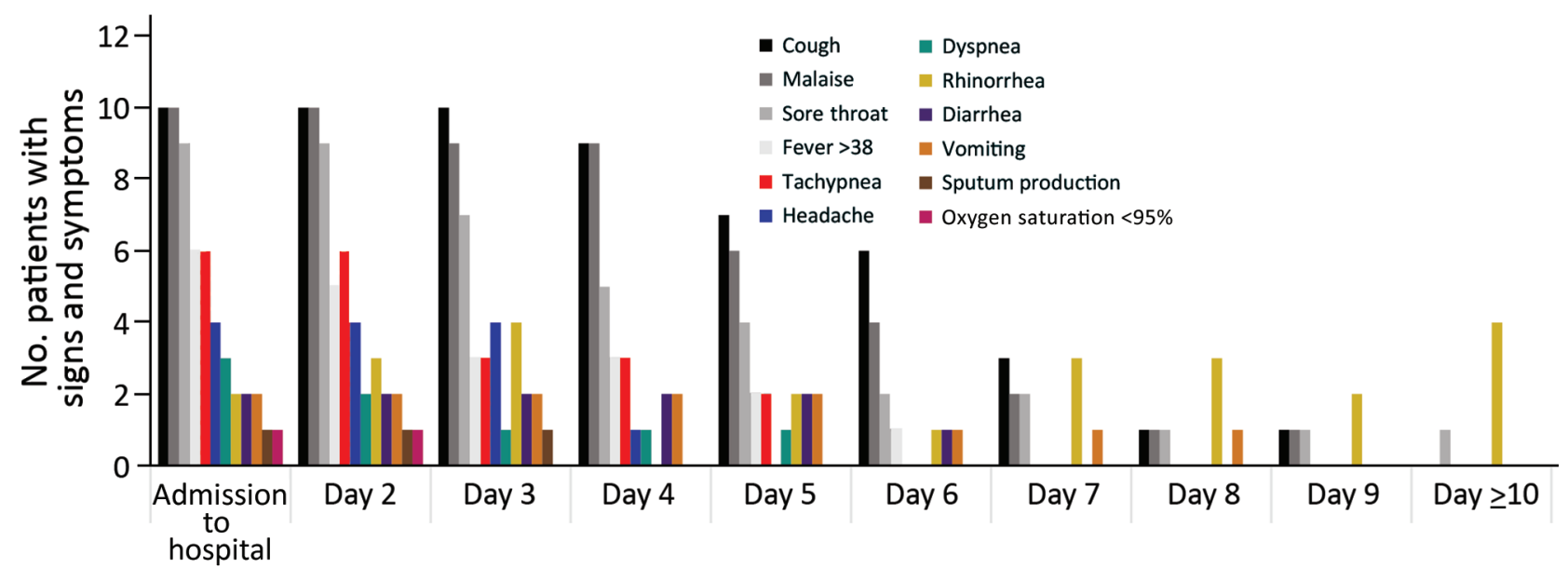

Figure 1. Number of patients with signs and symptoms by days following admission based on 11 patients with confirmed coronavirus disease, Bamrasnaradura Infectious Diseases Institute, Bangkok, Thailand, January 8-31, 2020

while transporting symptomatic travelers from China, a mechanism of exposure that has been described elsewhere (3-5). Patient 10 did not seek care for 10 days after his reported onset of fever. In Thailand, workers in the tourist industry, including those who transport tourists, are among the risk groups monitored for occupational exposures under updated clinical practice guidelines (6).

Table 2. Clinical illness history and calculated intervals of confirmed COVID-19 patients in Bamrasnaradura Infectious Diseases Institute, Bangkok, Thailand, 2020*

\begin{tabular}{|c|c|c|c|c|c|c|c|c|c|c|c|c|c|c|}
\hline \multirow[b]{2}{*}{ Duration of signs and symptoms, $d$} & \multicolumn{11}{|c|}{ Patient no. } & \multirow{2}{*}{$\begin{array}{l}\text { Median no. } \\
\text { days since } \\
\text { symptom } \\
\text { onset (IQR) }\end{array}$} & \multirow{2}{*}{$\begin{array}{l}\text { Mean no. } \\
\text { days since } \\
\text { symptom } \\
\text { onset (SD) }\end{array}$} & \multirow{2}{*}{$\begin{array}{c}\text { T-test } \\
\text { comparison } \\
\text { between } \\
\text { means }\end{array}$} \\
\hline & 1 & 2 & 3 & $4 \dagger$ & 5 & 6 & 7 & 8 & 9 & 10 & 11 & & & \\
\hline Onset of symptoms & 0 & 0 & 0 & NA & 0 & 0 & 0 & 0 & 0 & 0 & 0 & NA & NA & NA \\
\hline Onset of fever & 2 & 0 & 0 & NA & 0 & 0 & 9 & 0 & 1 & 0 & 0 & $0(0-1.25)$ & $1.2(2.8)$ & - \\
\hline First medical visit & 4 & 2 & 4 & 0 & 3 & 4 & 13 & 2 & 3 & 3 & 2 & $3(2-4)$ & $3.6(3.3)$ & - \\
\hline Admitted to BIDI & 4 & 2 & 4 & 0 & 3 & 4 & 13 & 2 & 3 & 8 & 5 & $4(2-5)$ & $4.4(3.5)$ & - \\
\hline SARS-CoV-2 RNA detected & 4 & 2 & 4 & 0 & 3 & 4 & 13 & 2 & 3 & 8 & 5 & $4(2-5)$ & $4.4(3.5)$ & - \\
\hline Fever resolution & 4 & 3 & 6 & NA & 6 & 4 & 13 & 4 & 6 & 13 & 11 & $6(4-11.5)$ & $7.0(3.9)$ & - \\
\hline Clinical resolution & 13 & 10 & 11 & NA & 9 & 9 & 17 & 15 & 9 & 13 & 13 & $12(9-13.5)$ & $11.9(2.8)$ & - \\
\hline SARS-CoV-2 RNA undetectable & 14 & 10 & 13 & 4 & 9 & 26 & 24 & 29 & 9 & 14 & 30 & $14(9-26)$ & $16.5(9.1)$ & - \\
\hline Discharge & 15 & 11 & 14 & 6 & 15 & 29 & 26 & 32 & 11 & 16 & 33 & $15(11-29)$ & $18.9(9.4)$ & - \\
\hline \multicolumn{15}{|l|}{ Calculated intervals } \\
\hline Admission to discharge & 11 & 9 & 10 & 6 & 12 & 25 & 13 & 30 & 8 & 8 & 28 & $11(8-25)$ & $14.5(8.7)$ & - \\
\hline $\begin{array}{l}\text { Fever resolution to SARS-COV-2 } \\
\text { RNA undetectable }\end{array}$ & 10 & 7 & 7 & NA & 3 & 22 & 11 & 25 & 3 & 1 & 19 & $9(3-19.75)$ & $10.8(8.4)$ & - \\
\hline Admission to fever resolution & 0 & 1 & 2 & NA & 3 & 0 & 0 & 2 & 3 & 5 & 6 & $2(0-3.5)$ & $2.2(2.1)$ & - \\
\hline $\begin{array}{l}\text { Fever resolution to clinical } \\
\text { resolution }\end{array}$ & 9 & 7 & 5 & NA & 3 & 5 & 4 & 11 & 3 & 0 & 2 & $5(3-7.5)$ & $4.9(3.3)$ & - \\
\hline Admission to clinical resolution & 9 & 8 & 7 & NA & 6 & 5 & 4 & 13 & 6 & 5 & 8 & $7(5-8.25)$ & $7.1(2.6)$ & - \\
\hline Fever onset to fever resolution & 2 & 3 & 6 & NA & 6 & 4 & 4 & 4 & 5 & 13 & 11 & $5(4-7.25)$ & $5.8(3.5)$ & - \\
\hline $\begin{array}{l}\text { Admission to SARS-COV-2 RNA } \\
\text { undetectable }\end{array}$ & 10 & 8 & 9 & 4 & 6 & 22 & 11 & 27 & 6 & 6 & 25 & $\begin{array}{l}10(6- \\
22.75)\end{array}$ & $12.2(8.3)$ & - \\
\hline Fever resolution to discharge & 11 & 8 & 8 & NA & 9 & 25 & 13 & 28 & 5 & 3 & 22 & $\begin{array}{l}10(7- \\
22.75)\end{array}$ & $13.2(8.7)$ & - \\
\hline \multicolumn{15}{|l|}{ Fever duration by stratified condition } \\
\hline $\begin{array}{l}\text { Patients detected through airport } \\
\text { screening }\end{array}$ & 2 & 3 & 6 & - & - & - & - & - & - & - & - & $3(2-6)$ & $3.7(2.1)$ & 0.14 \\
\hline Patients seeking medical care & - & - & - & - & 6 & 4 & 4 & 4 & 5 & 13 & 11 & $5(4-11)$ & $6.7(3.7)$ & - \\
\hline \multicolumn{15}{|c|}{ Detectable SARS-COV-2 RNA duration by stratified condition } \\
\hline $\begin{array}{l}\text { Patients detected through airport } \\
\text { screening }\end{array}$ & 10 & 9 & 8 & - & - & - & - & - & - & - & - & $9(8-10)$ & $9.0(1.0)$ & 0.17 \\
\hline Patients seeking medical care & - & - & - & - & 6 & 22 & 11 & 27 & 6 & 6 & 25 & $11(6-25)$ & $14.7(9.6)$ & - \\
\hline
\end{tabular}

${ }^{*}$ COVID-19, coronavirus disease; NA, not applicable

tPatient 4 was asymptomatic throughout hospitalization and PCR results reflects days with detectable SARS-CoV-2 RNA following admission. 


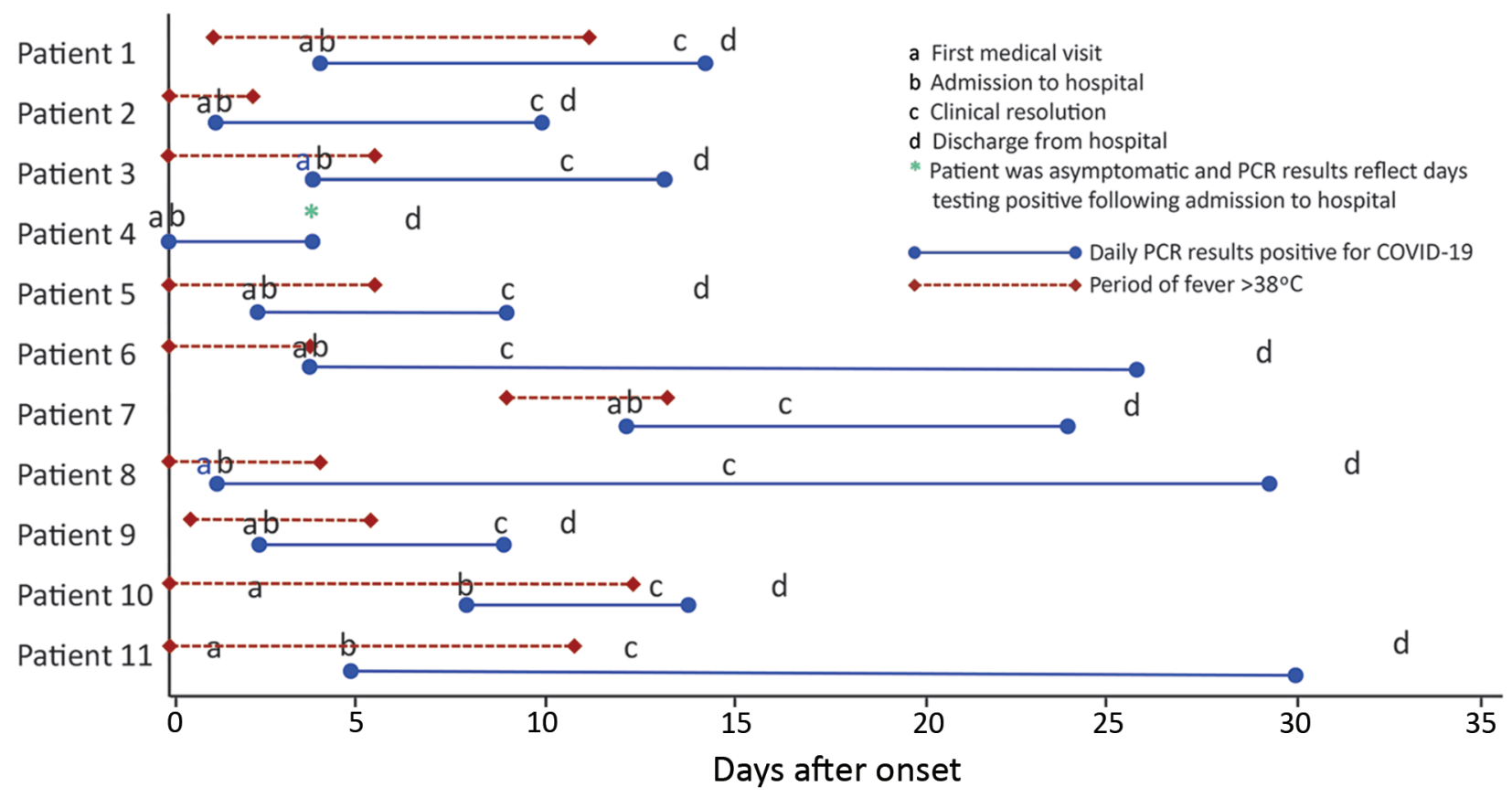

Figure 2. Clinical course for 11 patients with laboratory-confirmed COVID-19 by days since onset of their first symptom, Bamrasnaradura Infectious Diseases Institute, Bangkok, Thailand, January 2020. Blue solid bars indicate number of days each patient had detectable severe acute respiratory syndrome coronavirus 2 RNA. Red dashed bars indicate the number of days each patient had a fever $\geq 38^{\circ} \mathrm{C}$. Asterisk denotes that patient 4 remained asymptomatic during hospitalization with detectable viral RNA for 4 consecutive days. COVID-19, coronavirus disease.

We detected viral co-infections in 2 patients during their hospitalization. Patient 2 had an adenovirus co-infection, and patient 7 had an influenza A virus co-infection (Table 1). Patient 7 was hospitalized for 13 days and influenza might have contributed to his clinical course. In Thailand, influenza A infection occurs most frequently during the rainy season, July-November (7).

\section{Conclusions}

We describe the clinical characteristics, clinical management, and laboratory findings from 11 COVID-19 patients hospitalized at Bamrasnaradura Infectious Diseases Institute. Most were febrile, but the onset of fever occurred early in the course of illness and fever resolution occurred 5 days before full clinical recovery and 10 days before discharge. Although no patient required mechanical ventilation or intubation, all had radiographic evidence of pneumonia, even those without respiratory symptoms. Together, these findings suggest that whereas fever and lower respiratory illness are commonly observed, case definitions requiring both fever and lower respiratory illness as signs and symptoms might not have detected several of these cases, especially later in the clinical course of illness.
Clinical resolution occurred a median of 12 (913.5) days after illness onset, and these patients had detectable SARS-CoV-2 RNA in upper respiratory tract specimens for a median of 14 (9-26) days after illness onset (Table 2). However, patients became afebrile 6 days after illness onset, with a median of 9 (3-19.75) additional days of detectable SARSCoV-2 RNA in respiratory specimens after resolution of fever (Table 2). The required duration of hospitalization and observed period of viral RNA positivity for these patients underscore the potential burden of COVID-19 patients on hospital, diagnostic, treatment, and isolation capacities. Despite mild-to-moderate illness, the protracted period of SARS-CoV-2 RNA positivity in these patients' specimens might indicate a lengthy period of infectiousness and highlights risks to providers caring for COVID-19 patients.

Among persons of Chinese ethnicity in our study, only 3/9 who traveled from China were detected through airport screening. During the study period, $<7 \%$ of all persons under investigation for COVID-19 in Thailand were detected through airport screening (8). Given the proportion of cases identified through community surveillance, countries should not focus exclusively on point of entry 
screening or travel histories to detect cases of COVID-19, and maintaining healthcare providers' awareness remains critical.

Patient 4 had detectable SARS-CoV-2 RNA for 4 consecutive days, but we were only able to follow her for 7 days before she returned to China. Her case is an example of a person without reported symptoms but radiologic evidence of disease and detectable virus over several days. Other studies have described asymptomatic patients with upper respiratory specimens positive for SARS-CoV-2 (9), and evidence suggests such cases pose a risk for transmission (10-12).

Our case series has some limitations. Patients could have recall bias regarding symptom onset before hospitalization. We were unable to complete a 14-day observation for some patients because they returned to China after discharge, including patient 4, who had no reported respiratory symptoms.

The relatively long duration of hospitalizations in our study highlights the effects that current surveillance and isolation procedures can have on clinical care surge capacity. Duration of hospitalization was extended by Ministry of Public Health requirements for patients to remain in the hospital until symptom resolution and clearing of SARS-CoV-2 RNA in clinical samples. We observed that it took a median of 9 days to clear SARS-CoV-2 after fever resolution. In addition, we noted serial detection of SARS-CoV-2 RNA in respiratory specimens of an asymptomatic patient.

Our observations of possible viral co-infections in COVID-19 patients and the resolution of fever relatively early during clinical course also have implications for surveillance strategies. Specifically, case definitions requiring fever could miss COVID-19 cases, especially later in the clinical course, and surveillance strategies that test only for SARSCoV-2 could miss co-infections. Clinicians should consider the possibility of co-infection because the presence of other respiratory pathogens does not exclude the possibility of SARS-CoV-2 virus infection. Clinicians also need to better understand the relationship of RT-PCR detection of SARS-Cov-2 via multiple shedding routes (13) compared with the presence of culturable virus, especially in patients with few or no symptoms, because this might affect screening and isolation criteria. Whereas the current outbreak will undoubtedly change in character and magnitude, the information in this report could be combined with additional data sources to refine public health response and clinical management.
Data collection and analyses were approved by the institutional review board at Bamrasnaradura Infectious Diseases Institute, Bangkok, Thailand (IRB no. S004h/ 63_ExPD). The findings and conclusions in this report are those of the authors and do not necessarily represent the official position of the Centers for Disease Control and Prevention.

\section{About the Author}

Dr. Pongpirul is a nephrologist at Bamrasnaradura Infectious Diseases Institute, Bangkok, Thailand. She has led the management of the patients with COVID-19 admitted to the primary public COVID-19 referral center in Bangkok, Thailand. Her primary research interests, beyond COVID-19, include chronic kidney disease and histoplasmosis in patients infected with HIV, biomarkers of kidney diseases, and studies of kidney transplantation.

\section{References}

1. Department of Medical Sciences, Ministry of Public Health, Thailand. Diagnostic detection of novel coronavirus 2019 by real time RT-PCR. Version 0.23 January 2020. [cited 2020 Feb 16] https:// www.who.int/ docs/default-source/ coronaviruse/conventional-rt-pcr-followed-by-sequencingfor-detection-of-ncov-rirl-nat-inst-healtht.pdf?sfvrsn=42271c6d_4

2. Pongpirul WA, Pongpirul K, Ratnarathon AC, Prasithsirikul W. Journey of a Thai taxi driver and novel coronavirus. N Engl J Med. 2020;382:1067-8. https:/ / doi.org/ 10.1056/NEJMc2001621

3. Phan LT, Nguyen TV, Luong QC, Nguyen TV, Nguyen HT, Le $H Q$, et al. Importation and human-to-human transmission of a novel coronavirus in Vietnam. N Engl J Med. 2020;382:872-4. 10.1056/NEJMc2001272 https:/ / doi.org/10.1056/NEJMc2001272

4. Chan JF, Yuan S, Kok KH, To KK, Chu H, Yang J, et al. A familial cluster of pneumonia associated with the 2019 novel coronavirus indicating person-to-person transmission: a study of a family cluster. Lancet. 2020;395:514-23. https:/ / doi.org/10.1016/S0140-6736(20)30154-9

5. Wang D, Hu B, Hu C, Zhu F, Liu X, Zhang J, et al. Clinical characteristics of 138 hospitalized patients with 2019 novel coronavirus-infected pneumonia in Wuhan, China. JAMA. 2020;323:1061. PubMed https:/ / doi.org/10.1001/ jama.2020.1585

6. Department of Disease Control, Thailand. Guidelines for medical practice, diagnosis, treatment and prevention of healthcare-associated infection in response to patients with COVID-19 infection, revised version dated 16 February 2020 [cited 2020 Feb 21]. https://ddc.moph.go.th/viralpneumonia/ eng/file/guidelines/G_CPG_en.pdf

7. Prachayangprecha S, Vichaiwattana P, Korkong S, Felber JA, Poovorawan Y. Influenza activity in Thailand and occurrence in different climates. Springerplus. 2015;4:356. https:/ / doi.org/10.1186/s40064-015-1149-6

8. Department of Disease Control, Ministry of Public Health, Thailand. Novel coronavirus 2019 pneumonia situation: Thailand situation update on 15 February 2020 [cited 2020 Feb 16] https:/ / ddc.moph.go.th/viralpneumonia/eng/file/ situation/situation-no43-150263.pdf 
9. Zou L, Ruan F, Huang M, Liang L, Huang H, Hong Z, et al. SARS-Cov-2 viral load in upper respiratory specimens of infected patients. N Eng J Med. 2020;389:1177-9. https://doi.org/10.1056/NEJMc2001737

10. Bai Y, Yao L, Wei T, Tian F, Jin DY, Chen L, et al. Presumed asymptomatic carrier transmission of COVID-19. JAMA. 2020 Feb 20 [Epub ahead of print]. https:/ / doi.org/10.1001/ jama.2020.2565

11. Zhang W, Du R, Li B, Zheng X-S, Yang X-L, Hu B, et al. Molecular and serological investigation of 2019-nCoV infected patients: implication of multiple shedding routes. Emerg Microbes Infect. 2020;9:386-9. https:/ / doi.org/ $10.1080 / 22221751.2020 .1729071$

12. Yu P, Zhu J, Zhang Z, Han Y, Huang L. A familial cluster of infection associated with the 2019 novel coronavirus indicating potential person-to-person transmission during the incubation period. J Infect Dis. 2020 Feb 18 [Epub ahead of print] https:/ / doi.org/10.1093/infdis/ jiaa077

13. Chen N, Zhou M, Dong X, Qu J, Gong F, Han Y, et al. Epidemiological and clinical characteristics of 99 cases of 2019 novel coronavirus pneumonia in Wuhan, China: a descriptive study. Lancet. 2020;395:507-13. https:/ / doi.org/ 10.1016/S0140-6736(20)30211-7

Address for correspondence: Joseph Woodring, US Centers for Disease Control and Prevention-Thailand Ministry of Public Health Collaboration, DDC7 Building, Soi 4 Ministry of Public Health, Bangkok 10300, Thailand; email: wjd9@cdc.gov

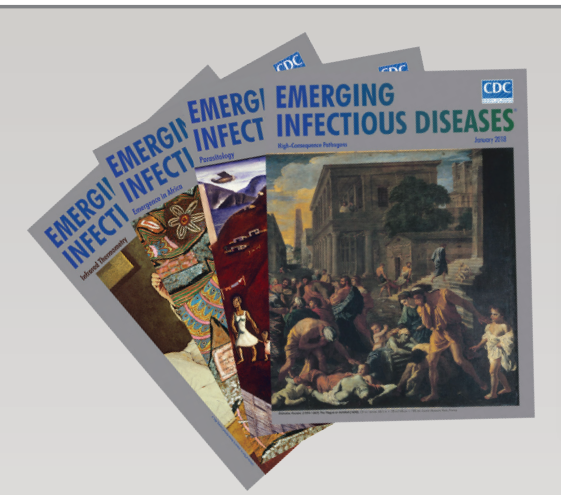

- Zika Virus Testing and Outcomes during Pregnancy, Florida, USA, 2016

- Sensitivity and Specificity of Suspected Case Definition Used during West Africa Ebola Epidemic

- Nipah Virus Contamination of Hospital Surfaces during Outbreaks, Bangladesh, 2013-2014

- Detection and Circulation of a Novel Rabbit Hemorrhagic Disease Virus, Australia

- Drug-Resistant Polymorphisms and Copy Numbers in Plasmodium falciparum, Mozambique, 2015

- Increased Severity and Spread of Mycobacterium ulcerans, Southeastern Australia

- Emergence of Vaccine-Derived Polioviruses during Ebola Virus Disease Outbreak, Guinea, 2014-2015

- Characterization of a Feline Influenza A(H7N2) Virus

- Japanese Encephalitis Virus Transmitted Via Blood Transfusion, Hong Kong, China

- Changing Geographic Patterns and Risk Factors for Avian Influenza A(H7N9) Infections in Humans, China

- Pneumonic Plague in Johannesburg, South Africa, 1904

- Dangers of Noncritical Use of Historical Plague Databases
- Recognition of Azole-Resistant Aspergillosis by Physicians Specializing in Infectious Diseases, United States

- Melioidosis, Singapore, 2003-2014

- Serologic Evidence of Fruit Bat Exposure to Filoviruses, Singapore, 2011-2016

- Expected Duration of Adverse Pregnancy Outcomes after Zika Epidemic

- Seroprevalence of Jamestown Canyon Virus among Deer and Humans, Nova Scotia, Canada

- Postmortem Findings for a Patient with Guillain-Barré Syndrome and Zika Virus Infection

- Rodent Abundance and Hantavirus Infection in Protected Area, East-Central Argentina

- Two-Center Evaluation of Disinfectant Efficacy against Ebola Virus in Clinical and Laboratory Matrices

- Phylogeny and Immunoreactivity of Human Norovirus GII.P16-GII.2, Japan, Winter 2016-17

- Mammalian Pathogenesis and Transmission of Avian Influenza A(H7N9) Viruses, Tennessee, USA, 2017

- Whole Genome Analysis of Recurrent Staphylococcus aureus t571/ST398 Infection in Farmer, lowa, USA 